\section{New Trends and Issues Proceedings on Humanities and Social Sciences}

Issue 1 (2017) 18-25

ISSN 2421-8030

www.prosoc.eu

Selected paper of 8th World Conference on Educational Sciences (WCES-2016), 4-8, February 2016, University of Alcala, Madrid, Spain.

\title{
Building vocational skill training center for unemployed women to eradicate the cycle of poverty in District Nowshera, Pakistan
}

Alina Babara*, Department of Architecture, University of Engineering \& Technology (UET) Peshawar, Abbottabad Campus, College road Mandian, Abbottabad -22010, Pakistan.

Ashraf Ali Babar ${ }^{\text {b }}$ North West General Hospital \& Research Center, phase 5 Hayatabad, Peshawar -25000, Pakistan.

Shahid Mansoor Khan', Department of Architecture,UET Peshawar, Abbottabad campus, College road Mandian, Abbottabad- 22010, Pakistan.

Shabir Ullah Qureshi ${ }^{\text {d }}$ Department of Architecture, UET Peshawar, Abbottabad campus, College road Mandian, Abbottabad- 22010, Pakistan.

\section{Suggested Citation:}

Babar, A., Babar, A.A., Khan, S.M. \& Qreshi, S. U. (2017). Building vocational skill training center for unemployed women to eradicate the cycle of poverty in District Nowshera, Pakistan. New Trends and Issues Proceedings on Humanities and Social Sciences. [Online]. 01, pp 18-25. Available from: www.prosoc.eu

Selection and peer review under responsibility of Jesus Garcia Laborda, University of Alcala, Spain

${ }^{\circ} 2017$ SciencePark Research, Organization \& Counseling. All rights reserved.

\section{Abstract}

Vulnerable and unemployed women of Nowshera district have no opportunity in their region to create their own employment and sustainable livelihood in order to redeem themselves and their families, out of extreme poverty. Vocational training (VT) is expected to offer skills to uneducated and jobless women there. Vocational training is an essential tool for integrating special people in society and makes them a productive member of community. This paper presents findings of an exploratory study conducted on vocational Center's of Nowshera district, Khyber Pakhtunkhwa.

Keywords: Vocational training, kills development, homeless women, uneducatedhusbands, poverty reduction, rural employment.

* ADDRESS FOR CORRESPONDENCE: Alina babar , Department of Architecture, University of Engineering \& Technology (UET) Peshawar, Abbottabad Campus, College road Mandian, Abbottabad -22010, Pakistan.

E-mail address: alinababar1992@gmail.com / Tel.: +0-425-248-0011 
Babar, A., Babar, A.A., Khan, S.M. \& Qreshi, S. U. (2017). Building vocational skill training center for unemployed women to eradicate the cycle of poverty in District Nowshera, Pakistan. New Trends and Issues Proceedings on Humanities and Social Sciences. [Online]. 01, pp 18-25. Available from: www.prosoc.eu

\section{Introduction}

Education and skills development are central to agricultural and rural employment. They prepare mostly young people for work in the formal and informal sector in rural areas and thus play an important role in poverty reduction. The vocational training is an essential tool for integrating special people in society and makes them productive members of community.

\subsection{Problem statement}

There is no opportunity for vulnerable, unemployed and homeless women of Nowshera district to create their own employment and sustainable livelihood in order to redeem themselves and their families, out of extreme poverty. There are 47 union councils in Nowshera district. Women Vocational center is required in every Union Council but currently there are only 11 vocational centers of which only two are active; vocational center in Dagi (30-35 students/year) and Whisper Center (50- 60 student/semester) in Pirpiai Union Council (Interviews and questionnaires) (Case study of whisper skill center).

\subsection{Target area (Amangarh Union Council)}

Amangarh Union Council is located in vicinity of Whisper Center, Pirpiai. It is one of the poor Union Councils of Nowshera district. The project will be proposed for Amangarh Union Council and will also cater the neighborhood villages including Khat kallay, Janabad and Pirpiai in Nowshera district of Khyber Pakhtunkhwa, Pakistan.

There is no platform for the women to learn valuable skills. Statistics shows that literacy rate in Amangarh Union Council are very low; 18\% (Questionnaires filled from women of target villages). Because of low literacy rate uneducated husbands, fathers and brothers do not allow their wives, daughters and sisters to go to learn and earn in places where men are involved. It is difficult for the poor families to meet their basic needs.

\subsection{Purpose}

The purpose of vocational training center is to encourage and teach poor families to earn their own living. The center will be designed to equip women with adequate skills in handcraft making etc. This will give women an opportunity to create employment for them as a result of improved capacities.

\subsection{User Group}

Skill training center will be for women of 15 years of age or older from any class that are working women, housewives or students.

\subsection{Objectives}

This study has following objectives:

- To enhance the understanding of culture and development of handicrafts by building activity 
Babar, A., Babar, A.A., Khan, S.M. \& Qreshi, S. U. (2017). Building vocational skill training center for unemployed women to eradicate the cycle of poverty in District Nowshera, Pakistan. New Trends and Issues Proceedings on Humanities and Social Sciences. [Online]. 01, pp 18-25. Available from: www.prosoc.eu

- Identification of vocational skill training areas

- To enlist the cultural crafts to be incorporated in skill center

- To provide social interactive platform

- To provide a platform for earning to ensure employment opportunities

- To ensure products marketability by providing cultural bazaar

- To ensure strong sense of affection for the place by following ergonomic design principles

\subsection{Research Methodology}

This study is based on the information obtained from available documents, internet and from observations made during visits to vocational centers, Union Council office and villages of Nowshera district. Questionnaire, interviews, field observations and literature review were used as tools to gather the information needed to answer research problems.

The study involved the case studies of following vocational centers. The first three vocational centers are located in Pakistan and fourth one is located in India.

- $\quad$ APWA (All Pakistan Women's Association) Zari Sarfaraz Center

- Whisper Islamic and Skill Training Center

- Dagi Vocational Center

- $\quad$ Barli Development Institute for Rural Women, Indore (case study of Barli Institute)

The vocational center dataset consisted of interviews with students and staff conducted during field work, field observations and surveys.

The study primarily drew on individual interviews with the unemployed women $(n=50)$, poor villagers, trainers in vocational centers, students of Whisper Training Center $(n=60)$ and the staff involved in their training. A total of 120 women and 5 men participated in interviews and questionnaires. The women interviewed were between 16 and 40 years of age.

\section{Results and discussions}

\subsection{Result obtained from questionnaires}

The questionnaire was intended to determine training programs to be provided for unemployed women of Nowshera district (Questionnaires filled from women of target villages).

- $\quad$ Sample population (50 households)

- $\quad 74 \%$ women want to attend vocational center

- $\quad 58 \%$ women will go to learn new skills in vocational centers

- $\quad 74 \%$ women will start home business after learning skills in vocational center

- $26 \%$ will start earning in the same center 
Babar, A., Babar, A.A., Khan, S.M. \& Qreshi, S. U. (2017). Building vocational skill training center for unemployed women to eradicate the cycle of poverty in District Nowshera, Pakistan. New Trends and Issues Proceedings on Humanities and Social Sciences. [Online]. 01, pp 18-25. Available from: www.prosoc.eu

The results of questionnaire indicated that unemployed women of Nowshera district preferred learning handicraft skills over other skills including cooking, beautician and home décor skills. The following Figure 1 and Figure 2 present the summary of percentage distribution of women by skill training programs (Questionnaires filled from women of target villages).

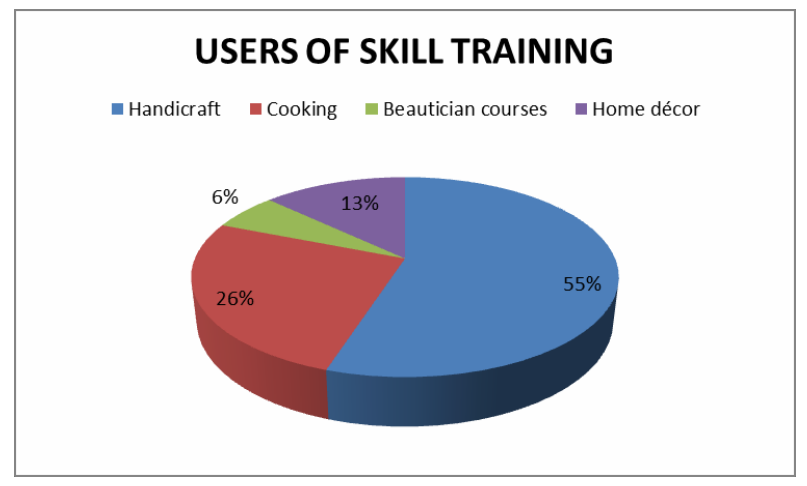

Figure 1. Percentage distribution of women by skill training programs

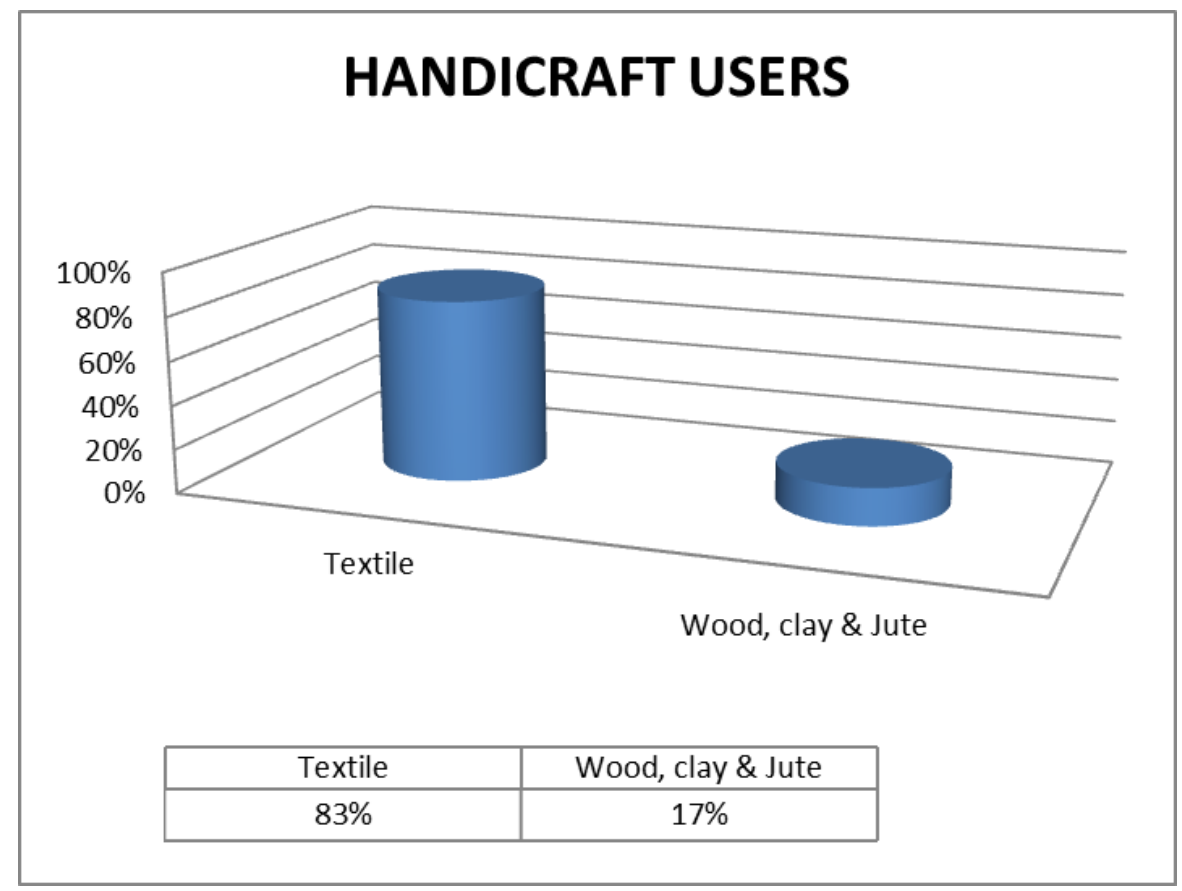

Figure 2. Percentage of users of each skill 
Babar, A., Babar, A.A., Khan, S.M. \& Qreshi, S. U. (2017). Building vocational skill training center for unemployed women to eradicate the cycle of poverty in District Nowshera, Pakistan. New Trends and Issues Proceedings on Humanities and Social Sciences. [Online]. 01, pp 18-25. Available from: www.prosoc.eu

\subsection{Result obtained from interviews (Information of Amangarh)}

The following information was gathered from the union councilor of Amangarh being interviewed. The literacy rate of Amangarh and Khat Kallay (village) is $18 \%$. Social and financial issues being faced by the villagers of Nowshera district include drug addiction, terrorism, and unemployment. There is only 1 Government Primary School for boys situated in Amangarh with the capacity of 200 students and only one teacher. There is one college; Ghosia Technical College for boys.

There is no educational, recreational or skill learning facilities for the women of Amangarh Union Council of district Nowshera. $5 \%$ women worked in the Textile Mill (Amangarh, Nowshera) when it was in running condition. Family size averages from 3 to 8 members. Sources of income solely depends on the following: Fishing, security guards, peons, mechanics, denting, painters, masonry workers, machine operators and workers men worked as workers in factories but now there is no opportunity for men and women because oil factory \& paper mills have been closed for the last 3 years. Extent of flood in Amangarh was not much but it damaged internal roads, sanitation system, and drinking water pipes. $1 \%$ of criminal case is recorded in Local Police Station and $25 \%$ drug addiction cases are registered. Unemployment, lack of education and health facilities are the major causes of crime and drug addiction. There is not any evidence of gender based violence (GBV) in any Police Station of Amangarh and Khat Kally, Nowshera.

\section{Statistical information}

\subsection{Union council level statistical data: (Case study of whisper skill center)}

Pirpiai is located in the neighborhood of target area; Amangarh Pirpiai Union Council; population (2014) $=90,260$ (Falling Rain Genomics). The literacy rate is $99 \%$ and number of vocational centers is 1 (Whisper Skill Training Center). Number of admission applications in Whisper center $=100$ / semester Student enrollment $=60 /$ semester. Calculating percentage of students enrolled in existing vocational center in Pirpiai: 100/90260 × 100 $=0.1 \% 3.2$. District level statistical data: (Pakistan Bureau of statistics)

Attock is located in the neighborhood of district Nowshera District Attock population (1998) = $1,274,935$ people. Female $(50.08 \%)=6,38,597$ people. No. of Gov. vocational institutes -Women $(2013-2014)=7$ Total female student enrollment $=1028$ people. Calculating percentage of students enrolled in existing vocational center in Attock district: 1028/ $638597 \times 100=0.16 \%$.

\subsection{Average annual growth rate of students (Pakistan Bureau of Statistics)}

Vocational Centers $=17.7 \%$.

\section{User analysis for proposed Skill Training Center}

The following figure illustrates the population of Amangarh, Khat Kallay and Janabad villages located in district Nowshera, Pakistan (Bureau of Statistics, KPk) (Falling Rain Genomics). 
Babar, A., Babar, A.A., Khan, S.M. \& Qreshi, S. U. (2017). Building vocational skill training center for unemployed women to eradicate the cycle of poverty in District Nowshera, Pakistan. New Trends and Issues Proceedings on Humanities and Social Sciences. [Online]. 01, pp 18-25. Available from: $\underline{\text { www.prosoc.eu }}$

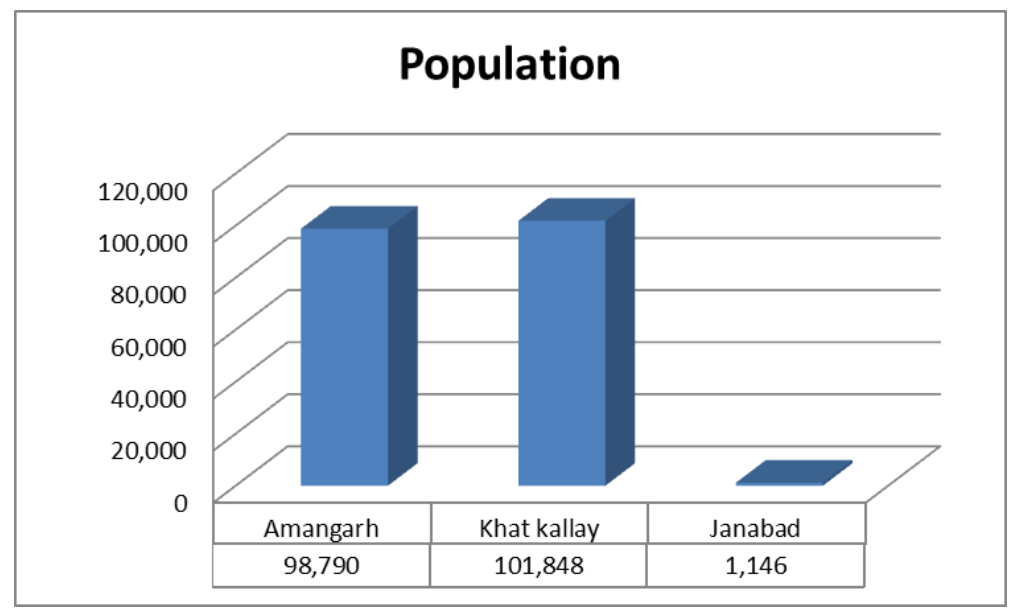

Figure 3. Population of target villages

Total population $=2,01,784$.

Sex composition: $47.9 \%$ (Bureau of Statistics, KPk)

Women in Nowshera $=47.9 / 100$ x 2, 01,784 = 96,654 women.

Skill Training center $=0.16 \%$ (calculated in section 3.2 above).

$0.16 / 100 \times 96,654=155$ users.

Annual growth $(17.7 \%)=0.177$ (see section 3.3 above) .

Students after 20 years $20 \times 0.177=3.54$

$3.54 \times 155=549$.

Total users $=155+549=704$ people.

Percentage distribution of the users below 15 years is summarized in Figure 4 and shown below (Bureau of Statistics, KPk). 


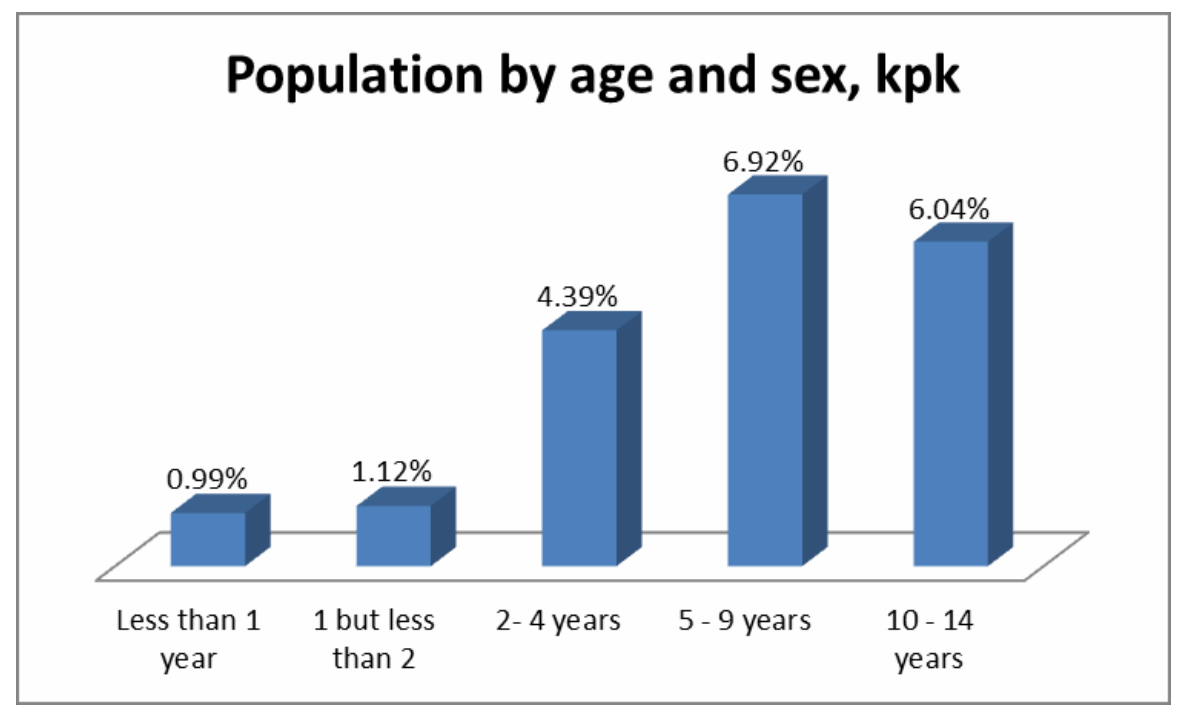

Figure 4. Percentage distribution of population by age and sex, KPK

\subsection{Users of skill training center}

Total users $=704$ people.

Children from 14 years of age and younger $=19.46 \% 19.46 / 100 \times 704=137(<15$ years $)$.

Users above 15 years of age: $704-137=567$ Total users ( $>15$ years): 567 users per semester.

Users of each training program are calculated from figure $1 \& 2$ and summarized as follows; (Questionnaires filled from women of target villages).

Handicrafts $=312$ users.

- $\quad$ Textile $=259$ users

- Wood $/$ clay $=53$ users Cooking $=147$ users Beautician $=34$ users

\subsection{Required Facilities based on study conducted}

Textile department: Basic and advance tailoring; hand and machine embroidery; hand and machine knitting; dress making and dress designing; lace making; ribbon work; string art; fabric painting.

Wood, clay and jute department: Bead work; ceramic art; clay Pottery; pyrography; jute handicraft.

Culinary department ( 6 teaching kitchens), Beautician department ( 2 beauty salons), Home décor department (3 labs).

\section{Conclusion}

Amangarh is a popular destination that has so much potential for the learning skills but there are no facilities for women. There is great demand for vocational training in the target villages (Janabad, Amangarh Pirpiai and Khat kallay) of district Nowshera.

The education and training of women and girls is critical to the well-being and advancement of communities and nations. Access to knowledge is the right of every human being, as is participation in 
Babar, A., Babar, A.A., Khan, S.M. \& Qreshi, S. U. (2017). Building vocational skill training center for unemployed women to eradicate the cycle of poverty in District Nowshera, Pakistan. New Trends and Issues Proceedings on Humanities and Social Sciences. [Online]. 01, pp 18-25. Available from: www.prosoc.eu

its generation, application and diffusion. Efforts to educate women and girls should be increased, and they should emphasize spiritual and moral principles, a rethinking of human nature, systematic participation, and global solidarity.

There is an explicit relationship between the physical characteristics of vocational buildings, and the spaces within them, and outcomes. Poor building conditions make it more difficult for teachers to teach and pupils to learn. Every effort should therefore be made in the design stage to create the ideal conditions for learning to take place.

\section{Acknowledgements}

Many people and organizations collaborated to produce this report.

Firstly I have to express my gratitude to the staff and students of Whisper Skill Training Center who understood the potential value of this work and strongly supported the study.

Thanks also go to the head of APWA Zari Sarfaraz center, Peshawar districts and head of Amangarh Union Council of Khyber Pakhtunkhwa that were involved in the post-occupancy evaluations. They took time from their very busy schedules to share information.

Dr. Ghosia Saeed has helped me in the publication process. This report could not have been completed without her contributions. I appreciate all this help.

\section{References}

Barli Development Institute for Rural Women. Retrieved from: http://news.bahai.org/story/176 http://creative.sulekha.com/visiting-the-barli-development-institute-for-rural-womenindore 453864 blog http://www.reocities.com/rainforest/2519/.

Bureau of statistics, Khyber Pakhtunkhwa. Retrieved from: http://kpbos.gov.pk/publications.php.

Falling Rain Genomics. Retrieved from: http://www.fallingrain.com/world/PK/03/Pir Pai2.html.

IMMAP Map Catalog: Pakistan. Retrieved from: http://immap.org/?page id=1371\&cat=17.

Interview and questionnaire filled from Amangarh Union Councilor and head of Whisper Islamic and Skill centerCenter located in Nowshera, Pakistan Case study of Whisper Skill Center Pirpiai, Nowshera. Questionnaires filled from st udents and staff of Whisper Center

Khyber Pakhtunkhwa, official gateway to government. Retrieved from: http://www.khyberpakhtunkhwa.gov.pk/index.php.

Pakistan Bureau of Statistics [National Education Census Pakistan]. Retrieved from: http://www.pbs.gov.pk/content/national-education-census- 2005-pakistan.

Questionnaires filled from women of poor families of target villages; Amangarh, Pirpiai, Khat Kallay and Janabad villages of Nowshera district. 